\title{
A TANÁRI PÁLYAVÁLASZTÁST NÉPSZERŰSÍTŐ MÉDIAESZKÖZÖK ANGLIÁBAN
}

\section{TARNÓC ANDRÁS}

\author{
az Eszterházy Károly Főiskola Bölcsészettudományi Karának \\ tanszékvezető főiskolai tanára \\ tarnoca@ektf.hu
}

\begin{abstract}
Jelen tanulmány a pedagógus pályarekrutáció Angliában alkalmazott elektronikus, fóként internetes média termékeit vizsgálja kommunikációs szempontok alapján. A kutatás három fö kérdést vet fel: a célcsoport és cél meghatározását, a közvetített üzenetek vizsgálatát, illetve az alkalmazott nyelvi és metanyelvi eszközök elemzését. A tanulmány Veres-Szilágyi nyomán a kommunikációt, mint a kibocsátó (információforrás) és a befogadó (címzett) közötti gondolati közösséget létrehozó folyamatot értelmezi.
\end{abstract}

\section{Bevezetés}

Annak ellenére, hogy Angliában egyre több erőfeszítés történik a tanári pálya népszerüsítésére, az Oktatási Minisztérium (DfE) kimutatása szerint az iskolarendszer - elsősorban a közoktatás - tanárhiánnyal küszködik. 2014-ben a feltölthető 34890 főnyi keretszámból 32543 fö kezdte meg tanulmányait a tanárképzési programokban, amely gyakorlatilag 2000 betöltetlen leendő tanári álláshelyet jelent. Ha a tanárhiányt tárgyakra lebontva vizsgáljuk, látható, hogy technológia területen csupán 44 százalékos a betöltöttség, míg a matematika és fizika szakosoknak is csak 67 százaléka nyújt olyan tanulmányi teljesítményt, amely a tanári pályára is alkalmassá tenné őket ${ }^{1}$. Malcolm Trobe, az Association of School and College Leaders (Felsőoktatási Intézmények Vezetőinek Egyesülete) főtitkárhelyettese meglátása sokat mondó: „Egyszerüen szólva, nincs elegendő jó jelölt a tanári pályára!”

Következésképpen, a tanári pályára megfelelő jelöltek toborzása, vagyis az oktatói utánpótlás biztosítása kulcsfontosságúvá vált. Mivel a cél a minél szélesebb közönség elérése, a tanári pályaválasztás népszerüsítését célzó erőfeszítések az információ- és kommunikációtechnológiai eszközök, illetve az internet használata irányába tolódtak el. A paradigmaváltást többek között az első számú célközönség életkora és az internetbe, illetve az új médiába való beágyazottsága igazolja. Mivel

\footnotetext{
${ }^{1}$ URL: http://www.telegraph.co.uk/education/educationnews/11258232/Schools-warned-over-looming -teacher-recruitment-crisis.html Letöltés ideje: 2016. 01. 02.

${ }^{2}$ URL: http://www.telegraph.co.uk/education/educationnews/11258232/Schools-warned-over-loomingteacher-recruitment-crisis.html Letöltés ideje: 2016. 01. 02.
} 
a tanári pálya gyakorlatilag brand-dé, vagyis egy marketing folyamat tárgyává vált, több olyan médiatermék is készült, amely a világhálón, illetve a legnagyobb videó fájlmegosztón keresztül szólítja meg az érintetteket. A dolgozatban csoportosítandó és elemzendô média termékek az alábbi három fő célt szolgálják:

- A tanári pálya, mint egyéni és közösségi szintü katartikus örömforrás.

- A tanári pályára lépés lehetőségeinek diverzifikálása.

- A tanári pálya, illetve a tanár presztízsének növelése.

\section{A vizsgálat célja és szempontjai}

Jelen tanulmány a fenti célokat tükröző médiatermékek egyes kiválasztott reprezentatív példáinak kommunikációs szempontú elemzésére tesz kísérletet. A vizsgálat azonosítja azokat az eszközöket, amelyek elösegítik az adott médiatermékek hatékonyságát. A feltárt anyagokban a közvetlen szóbeli üzenetek, a meggyőzés céljából szerkesztett marketing eszközök, illetve a szereplök metanyelvi kommunikációja (testbeszéd, hanglejtés, öltözet, színek) kerülnek elemzésre. Tanulmányomban az adott médiatermékek vizsgálatát három szempont alapján végzem:

- a kommunikáció célja és célcsoportja;

- a médiatermék által közvetített üzenet;

- a felhasznált nyelvi és metanyelvi eszközök.

Megközelítésemben több ismert kommunikációs meghatározás és elmélet (ShannonWeaver, 1949; Laswell; 1948) közül a Veres-Szilágyi-féle kommunikációs elméleti keretet (2007) használom, amely szerint: „a kommunikáció olyan tevékenység (folyamat), amely a kibocsátó (információforrás) és a befogadó (címzett) között gondolatok közösségét vagy egyezségét hozza létre" (Lendvai és Gál, é. n.). A fö hangsúly a gondolatok közösségén és egyezségén van, vagyis nem is annyira azt kell néznünk, hogy - Laswell után szabadon - ki mit mond, milyen csatornán és kinek, hanem hogy az adott kommunikációs eszközök segítik e gondolati közösség megteremtését. ${ }^{3}$

\footnotetext{
${ }^{3}$ Harold Laswell 1948-ban dolgozta ki öt elemes kommunikációs modelljét elsősorban a tömeg kommunikációra fókuszálva. A gondolati közösség értelmezésemben azt jelenti, hogy a célközönség tagja nyitottá válik, illetve meggyőződik arról, hogy a tanári pályát érdemes választani. Ugyanakkor, nyilvánvaló, hogy az adott média termék ilyen irányú hatékonysága nehezen mérhető, és csak a tanári programokba való jelentkezés, illetve a tanári pályára váltó szakemberek száma növekedése adhat támpontot.
} 


\section{A tanári pályarekrutáció média termékei}

\section{A tanári pálya mint egyéni szintü katartikus örömforrás: Staff Room}

Az angol oktatáspolitika kiemelt célja a legjobb jelöltek megnyerése a tanári pályára. A fenti céltól vezérelve az angliai Oktatási Minisztérium elkészített egy interaktív digitális, egyben multimédia anyagot, amelynek címe Staff Room (Tanári szoba). A fö üzenet maga a prezentáció címe: Teaching: your future, their future. (A tanítás: a te jövőd, az ő jövőjük $)^{4}$. A portál célja a tanári pálya presztízsének növelése mellett a tanári munka és munkakörülmények újra pozicionálása, miközben a mellékelt videóprezentációk, illetve az irányított interjúk a pálya önjutalmazó, örömgeneráló hatásait mutatják be.

A portál gyakorlatilag virtuális iskolaként müködik. A bevezető részben az intézmény igazgatója (headteacher) bemutatja az iskolát, miközben a tanári pályával kapcsolatos kérdéseket tesz fel a nézőknek. A szóban forgó szegmensben két dolog válik szembetünővé: az egyik, hogy az igazgató igen fiatal, illetve rendkívül gyorsan, dinamikusan lépkedve mutatja be az iskolát. Mindez sejteti a pályán való gyors előrejutás lehetőségét. A spot megteremti az egész prezentáció rendkívül pozitív alaphangulatát, amely végül az igen kedvező fizetési adatok bemutatásával zárul. A videó fő része a Staff Room, vagyis a tanári szoba bemutatása. A szoba nem a hagyományos magyar iskolákban ismeretes hosszú asztalos elrendezésü, hanem hasonló egy kávézó térbeli berendezéséhez, kényelmes fotelek vannak elhelyezve, a tanárok egymással szemben ülnek, nincsenek egymástól elkülönítve, ugyanakkor mindenkinek megvan a magánszférája. Mindazonáltal a néző azt is láthatja, hogy a tanár, annak ellenére, hogy egyedül áll az osztály előtt, nincs magára hagyva, valójában egy csapat része. A tanári szoba és maga az iskola is rendkívül jól felszerelt. A videó során 6 tanárral ismerkedünk meg, rövid interjúk, illetve óra illusztrációk keretében.

A kommunikáció személyre szóló, egyben informális, kötetlen, mintegy viszszaadva az iskola lazább légkörét. A tanárok fiatalok, energikusak, a diák és tanár közötti korkülönbség nem olyan nagy, hogy gátolná a sikeres generációk közötti kommunikációt. Habár mind a tanárok, mind a diákok formális megjelenésüek, egyenruhát viselnek, látható a törekvés, hogy az angol iskolarendszerrel kapcsolatos negatív sztereotípiákat lerombolják. Az iskola mint partner mutatkozik, nem pedig ellenség, mint az tapasztalható volt olyan klasszikusok esetében, mint Lindsay Anderson If címü filmjében, (1968) vagy akár a Pink Floyd 1982-es The Wall címü albumában, ahol az egyén szabadságát és önkifejezését korlátozó angol iskolarendszer látványos elutasítására kerül sor.

\footnotetext{
${ }^{4}$ A portál elérhetősége URL: https://getintoteaching.education.gov.uk/ https://www.gov.uk/government/news/your-future-their-future-new-teacher-recruitment-campaign Letöltés ideje: 2016. 01. 02.
} 
Az adott kommunikáció célja a tanári pályáról való pozitív kép kialakítása, a tanári pálya megbecsültségének növelése. A videó irányított interjú formában szólaltatja meg a tanárokat. A kérdések a következők:

- Miért választotta a tanári pályát?

- Mit kapott a tanári pályától?

- Melyik órájára emlékszik vissza a legszívesebben?

- Ajánlaná-e másnak a tanári pályát?

A válaszok kiemelik a tanár motivációs szerepét, a tanítást mint örömforrást vagy önmegvalósítási tevékenységet, a diákok életére gyakorolt hatást, a kihívásokkal teli életformát. Az interjúk mellett az adott szaktantárggyal kapcsolatos órákba is betekinthet az érdeklődő. Az órák dinamikusak, érdekesek, látható céljuk a diákok figyelmének megragadása, az érdeklődés felkeltése. A diákcsoportok - hasonlóan a tanári karhoz - etnikailag heterogének.

A prezentáció célja egyértelmủen a pályarekrutáció, mivel az egyetemista generáció nyelvén és annak eszközeivel szólítja meg a hallgatót. A tanári pályára való belépés folyamatának felidézése egyértelmü segítséget biztosít a pályaválasztásban bizonytalan fiatalnak. A kommunikáció üzenete: a tanári pálya lehetőség a jövő megváltoztatására, az egyén kilép a társadalmi elszigeteltségből, és tehet valamit a közjóért. A videó természetesen csak pozitív elemeket említ, az esetleges negatívumok is pozitívumhoz kapcsolva jelennek meg; ilyen például a fáradtság, ami a napi jól elvégzett munka után jelentkezik, vagy pedig az esetleges fegyelmezési vagy osztálymenedzselési problémák, amelyek egyben beépülnek a tanári pálya változatosságáról (nincs két egyforma diák, nincs két egyforma osztály) szóló beszámolókba.

Fontos az is, hogy az interjúk végén a néző a twitter segítségével megkapja a további kapcsolattartás lehetőségét. Ez is közelebb hozza az adott tanárt, és megteremti a személyes kapcsolat lehetőségét. Figyelemre méltó az is, hogy a bevezető rész után a jövedelem kérdése nem kerül szóba. A kiemelt pályajellemzők az érzelmi azonosulás (a tanár mint motivátor, a tanári pálya életmódosító ereje, a tanítás mint örömforrás) és a társadalmi presztízs.

A videóban alkalmazott nyelvi eszközök - „megkérdőjelez”, „kritizál”, „megért”, „teljesít” (question, criticize, understand achieve) - performatív, cselekvést sugalló kifejezések. Az igazgató a következö kontrasztelemekkel illusztrálja a tanári pályán elérhető pszichológiai jellegü, egyben önjutalmazó eredményeket: az ijedt félénk (frightened) diákból önbizalommal telt (confident) tanuló lehet, illetve az érdeklődést nem mutató (uninterested) ifjú céltudatossá, ambiciózussá válhat (ambitious). Az ellentétpárokra épülő hagyományos, de rendkívül hatásos retorikai eszközök mellett megjelenik a fokozás is, mivel a tanár a tehetséges diákot (gifted) kiemelkedően zseniális (brilliant) szintre emelheti. A portál órabejátszásokat is tartalmaz, amelyekben a hagyományos frontális tanítási módszerek dominálnak, 
ugyanakkor a tanár nem bújik el, nem zárja be magát a katedra mögé, hanem áll, járkál, élénken gesztikulál, szemkontaktust tart fenn, testtartásával, hanglejtésével nyitottságot sugall. Figyelemre méltó, hogy a tanár öltözete, illetve az osztályterem falai nem hagyományos hideg (kék, zöld, fekete) színüek: a többnyire halványsárga, vagy bézs háttér melegebb, nyitottabb attitüdöt sugároz.

\section{A tanári pálya mint közösségi szintü katartikus örömforrás: Teach First}

A Teach First (Taníts, mielőtt tanár leszel!) elnevezésü program célja, hogy orvosolja a társadalmi és gazdasági egyenlőtlenségekből fakadó hátrányokat, és segítse a kifejezetten hátrányos helyzetủ diákokat. A program gyakorlatilag a tanárképzés része, és segíti a hallgatókat a QTS (qualified teacher status, képesített tanár, a tanári pálya belépési szintje) megszerzésében. A két év időtartamú Teach First program hathetes felkészítéssel kezdődik, amelynek során a hallgatók megismerkednek az oktatási és társadalmi egyenlőtlenségek fogalmi és tartalmi hátterével, valamint az adott környezetben alkalmazható módszerekkel. A tanítás mellett a résztvevők 432 óra vagy 72 napnyi képzésben részesülnek. A tanítás folyamán mentori segítséget is kapnak, illetve egy tutor segítségével készülnek az egyetemi vizsgákra. A Teach First program jelenleg 980 partner iskolával müködik és 11 év alatt több mint 7000 tanárt biztosított szociálisan és gazdaságilag hátrányos helyzetủ diákok oktatására. ${ }^{5}$ Az első év elvégzése után a jelöltek NQT (newly qualified teacher, pályakezdő, kevesebb mint egy éve képesített) státuszba kerülnek, majd a második évben a QTS megszerzése után a végzős diákok a program nagyköveteivé válnak. A Teach First országos hálózat, a fövédnöke maga Károly, walesi herceg.

A Teach First program honlapja ${ }^{6}$ nem hagy kétséget a szociálisan és gazdaságilag hátrányos helyzetủ csoportok társadalmi felzárkóztatása iránti elkötelezettségéről, mivel azonnal szembesíti a látogatót az Egyesült Királyságban meglévő gyermekszegénység mértékével, ami jelenleg 3,6 millió gyermeket érint. Hasonlóan más rekrutációs célú oldalakhoz, itt is találhatunk a program sikerét tanúsító videó bejátszást. A filmrészlet mottója rendkívül hatásos, mivel felhívja a figyelmet arra, hogy egy tanár a diák egész életét meghatározó szerepet is játszhat, vagyis „Egy jó tanár a gyermek életének legfontosabb személyévé válhat.” („A great teacher can be the most important person in a child's life").

Természetesen ez a kijelentés súlyos tartalmat is hordoz, mivel a tanárra potenciális társadalomformáló szerepet is ruház, ami bizonyos esetekben a szülői felelősség terhének az iskolára hárítása veszélyét is magában rejtheti. A videó szereplöi a kamasz Sharif, a fekete kisebbségi közösség képviselöje, a tanár pedig középosztálybeli fehér férfi. A tanár felismerte, hogy diákja tanulmányi nehézségeit részben az otthoni problémák, a saját tanulási tér hiánya okozza. Következéskép-

\footnotetext{
${ }^{5}$ URL: http://www.teachfirst.org.uk/home Letöltés ideje: 2016. 01. 02.

${ }^{6}$ URL: http://www.teachfirst.org.uk/home Letöltés ideje: 2016. 01. 02.
} 
pen a tanár két évig minden pénteken az irodájában külön foglalkozott vele. A foglalkozások hatása több szinten mérhetö. Természetesen Sharif eredményei javultak, ugyanakkor nőtt az önbizalma is, mivel a tanár segített abban, hogy maximalizálja a benne rejlö tehetséget. Miközben Sharif mosolyogva hangoztatja tanára szavait /,Megcsináltad, haver!” (,, You sure did, buddy”) /, a néző átérzi a tanári munka potenciálisan katartikus és örömgeneráló hatását. A történetben nemcsak az fontos, hogy a tanár időt szánt a diákra, illetve, hogy felismerte a benne rejlő tehetséget, hanem hogy saját munka- és személyes zónáját megosztva partnerré tette diákját.

A kommunikáció célcsoportja természetesen a leendő tanár, aki már rendelkezik bizonyos mértékü társadalmi elkötelezettséggel. A médiatermék célja kettős, adományszerzés vagy támogatók szerzése a Teach First mozgalom számára, illetve a tanári pálya társadalmi presztízsének növelése. A bejátszás előtti szövegben az our teacher (a mi tanárunk) kifejezés büszkeséget és a szervezettel, továbbá, magával a tanári professzióval való azonosulást fejez ki. Az olyan kifejezések, mint empower (felhatalmaz, felszabadít), engaging (érdeklödést felkeltő), achieve (elér, teljesít), confidence (önbizalom) gyakorlatilag mind pozitív üzenetet hordoznak. A célközönség a középosztály, mint adományképes társadalmi csoport. A klip üzenete egyértelmü: a tanár életformáló, életmegváltoztató erővel bír. Ugyanakkor, ha a multikulturalizmus dinamikáján keresztül vizsgáljuk a kérdést, felmerülhet a fekete diák másodlagos helyzete, aki alárendelt iskolai pozíciójából - mint rosszul teljesítő diák - nem önerejéből, hanem a fehér föáramlatot képviselö férfi tanár segítségével tört ki.

A videó technikai szempontból először osztott képekkel dolgozik, és amint ezt a feliratok is jelzik, már a bejátszás elején megtörténik a szereplők kategóriába sorolása: Sharif: tanuló, Chris: tanár. Természetesen a tanár keresztnevének használata jelez egy bizonyos mértékü egalitárius szándékot, azonban a hierarchikus helyzet nyilvánvaló. Fontos az is, hogy a tanár teljes nevét megtudjuk, Mr. Fairbairn (fair, mint méltányos) de a diák csak keresztnéven van említve. Ami szintén érdekes, hogy egy marketing jellegü videóban gyakorlatilag „,belső marketing” tevékenységet is látunk. A tanár az adott matematikai alaptételt rímes mottóba foglalja (Always wise to factorise) és segít abban, hogy Sharif, a tehetséges, de a matematikát nem értő és nem szerető diák megszeresse az iskolát, más szóval „sikerrel adja el neki”. Figyelemre méltó, hogy Sharif a bejátszás elején az iskolát először nyügnek (chore) érezte és Mr. Fairbairn pozitív hozzáállása tette öt lelkes „fogyasztóvá.”

Jelen esetben a tanár nemcsak a diák kognitív szférájára hat, hanem pszichikai segítséget is nyújt. Sharif, aki az önértékelés nyilvánvaló hiányától szenvedve, lekicsinylő módon úgy utal saját személyére, mint someone like me, (olyasvalaki, mint én...) később, már saját bevallása szerint és teljesítménye tudatában az Aliz Csodaországbeli kalandjaiból ismert cheshiri macskaként vigyorog a világra. A videó színvilága, a bézs vagy világosbarna háttér, a tanár világos színű ruhája, az iskolai egyenruha hiánya könnyedséget, elfogadást, informálisságot sugároznak. A videó 
hatékonysága az érzelmi dimenzióban tapasztalható, mind megjelenésében, mind üzenetében a föáramlatnak címezi mondanivalóját.

\section{A tanári pályára lépés lehetőségeinek diverzifikálása}

Mivel a brit, egyben az angol társadalom egyre inkább multikulturálissá válik, fontos, hogy ne csak a hagyományos értékeket képviselő tanárok vegyenek részt az oktatásban, hanem megjelenjenek a bevándorló közösségek képviselői is. Ugyancsak lényeges a hátrányos helyzetü diákok megszólítása, vagyis a nagyvárosok szociálisan leszakadt, perifériára szorult területein lakók oktatásba való bevonása. A Teacher Support Network (Tanári Segítő Hálózat) és a National Union of Teachers (Országos Tanári Szakszervezet) által 2006-ban tartott internetes felmérés szerint így oszlik meg a kisebbségi tanárok aránya: 1,7 százalék fekete, 2,6 százalék ázsiai, 0,8 százalék vegyes etnikai hátterü, miközben a fehér tanárok aránya 94,3 százalék. Az etnikai és rasszbeli kisebbséget képviselö tanárok föként Londonban tanítanak, ahol a tanárok 11 százaléka fekete, 7,4 százaléka ázsiai. Az észak-keleti régióban ugyanakkor a tanárok 0,1 százaléka fekete és 0,4 százaléka ázsiai. Ugyanakkor az általános iskolai tanulók 21,9 százaléka, illetve a középiskolai tanulók 17,7 százaléka etnikai és rasszbeli kisebbségi csoportból származik.

A 238 válaszadó 61 százaléka állította, hogy diszkrimináció áldozata lett a munkája során. Ugyancsak kétszer olyan valószínü, hogy a kisebbségi hallgatók tanulmányaik befejezése előtt hagyják ott az egyetemet. Az Institute for Policy Studies és a London Metropolitan University által megtartott felmérés szerint a fehér tanárok 15-20 évnyi szakmai gyakorlattal kétszer nagyobb valószínüséggel léphetnek elöre, mint nem fehér kollégáik. ${ }^{7}$

A tanári pályára bevonandó demográfiai célcsoportok természetesen nem csak rassz alapúak. Gyakorlatilag két fő csoportról van szó: a tanárképző intézmények végzős és tehetséges diákjai, illetve a már egy más pályán eredményeket elért, ugyanakkor karrierváltást fontolgató felnőtt korú értelmiségiek. Azonban mindkét esetben találhatunk közös nevezőt. A szakmai tudás és felkészültség mellett igen fontos a társadalmi egyenlőség, a kulturális diverzitás, és a diákban szunnyadó potenciál kiaknázása iránti elkötelezettség. A tanár nem csupán a tudás birtokosa, vagyis egy hierarchikus rendszert megtestesítö figura, hanem az információs és kommunikációs technológia vívmányaival felfegyverzett tudásteremtő és azt megosztó, disszemináló személyiség. A tanár feladata az, hogy segítsen kinevelni egy olyan nemzedéket, ahol a fent jelzett társadalmi és gazdasági egyenlőtlenségek enyhülnek, vagy optimális esetben el is tünnek.

A Premier Plus program keretében Get into Teaching! (Vágj bele a tanításba!) gyüjtőnév alatt több videó készült. Jelen esetben a médiatermékek célja a tanári pá-

\footnotetext{
${ }^{7}$ URL: https://www.tes.co.uk/article.aspx?storycode=2622901) Letöltés ideje: 2016. 01. 02.
} 
lya belépési lehetőségeinek diverzifikálása. A Switching Career into Teaching ${ }^{8}$ spot (Karrierváltás: irány a tanári pálya!) olyan szakembereket szólít meg, akik habár jelentős eredményeket értek el eddigi pályájukon, elvesztették a belső motiváló eröt, és új kihívásokkal szeretnének szembenézni. Míg a Teach First a fiatalabb generációt célozza meg, ebben az esetben a középkorú vezető beosztású értelmiségi az üzenet tervezett befogadója. A nyitó jelenet egy középkorú bankvezetőt mutat, aki az 50. életévéhez közeledve éli át az osztályterem és a tanítás regeneráló erejét. Az angol kifejezés / „I give it a go.” (,,Belevágok.”) / szintén ezt a részben impulzív, egyben tervezett cselekvést sugallja. Nagyon érdekes az is, hogy több esetben megjelenik a tanári pályára való lépés mint vágyálom. Ezekben az esetekben a tanítás a második karrier lehetőségét veti fel. Ugyanakkor, mivel már érett személyekről van szó, nem feltétlenül a pályával kapcsolatos szakmai előremenetel felvillantása a cél, hanem inkább a belső képességek aktualizálása lehetőségének a bemutatása, az egyén tanulási és tanítási potenciáljának maximalizálása. Mindezek ellenére az anyagok tartalmaznak utalásokat a szakmai igények és a megfelelö jövedelem közötti egyensúly megtalálására. A pályaváltó, az előző szakmájában eredményes tanár (jelölt) számára adható legerősebb motivációt az egyik tanár vallomása adja meg: "Instead of working for a CEO, you are working for the kids." (,, A vállalati menedzsered helyett a gyerekekért dolgozol.”). Ez az a sarkalatos pont, ami a legnagyobb vonzerő lehet, vagyis itt jelenik meg a spirituális dimenzió. A tanári pálya idealizált képe éppen az üzleti szféra taposómalmából való kiszabadulás ígéretét hordozza magában.

A spotok megjelenése hasonló, az egyenletes, dinamikus, és kiszélesedést, illetve szakmai és személyes fejlődést sugalló zenei aláfestés, a nyitott testtartás, az arcokon látható mosoly, a dinamikus mozgás, továbbá a semleges színvilág elfogadást sugallnak. Fontos megjegyezni, hogy mindegyik pályaváltó kiemeli, hogy az első karrier során megszerzett és felhalmozott tudását és szakmai hátterét sikerrel tudta alkalmazni második pályáján is. A bankár, személyzeti vezető, régiségkereskedő mind olyan készségeket hoz a tanári pályára, amellyel gazdagítja azt. Ugyancsak kiemelendő, hogy a spot megerősíti a második karriert vállaló szakembert, hogy új pályáján nincs egyedül, szakmai segítséget és személyes támogatást kap.

\section{A tanári pálya, illetve a tanár presztízsének növelése}

A tanári pálya presztízsnövelését célozzák meg a motivációs jellegü prezentációk, ezek között említem meg a Teacher Training Agency (Tanárképző Hivatal) megbízásából készült, No one forgets a good teacher, / Egy jó tanárt senki nem felejt el (vagy némiképp más logikával fordítva: Mindenki emlékszik egy jó tanárra)/ vagy a Those who can, teach (Aki tudással rendelkezik, az tanít igazán) megnevezésủ programo-

\footnotetext{
${ }^{8}$ URL: https://getintoteaching.education.gov.uk/why-teach/career-changers Letöltés ideje: 2016. 01. 02.
} 
kat. Ezekben az esetekben a tanár mint a diák életére jelentősen ható erő, illetve mint a gazdasági szféra által nagyra értékelt képességek birtokosa jelenik meg.

A No one forgets a good teacher videóbejátszásának érdekessége, hogy csak zenei elemeket tartalmaz, az említett mottó csak a spot végén jelenik meg. A célcsoport ebben az esetben is a potenciális tanárjelölt, akit a pálya önjutalmazó, katartikus, és más spirituális szintü elemei motiválnak. Az üzenet közvetett módon utal a tanár életformáló szerepére. Maga a mottó is elemezhető: No one forgets a good teacher, vagyis Senki nem felejt el egy jó tanárt. Természetesen az elsődleges jelentés az emberi (személyes) és oktatási teljesítmény maradandóságára, illetve az elszemélytelenedett társadalomban való nyomot hagyásra utal. Ugyanakkor nemcsak egyéni, vagyis mikroszinten mozog a megközelítés, hanem eljut a mezoszintre, vagyis az iskolarendszer síkjára, illetve megcélozza a makroszintet, az össztársadalmi színteret is. A spot elején izgatott diák látszódik, érződik, hogy valamire vár, a feszültséget egy friss szellőből egyre erősödővé váló légmozgás oldja fel. Habár a tanár személye nem jelenik meg a képernyőn, Ö az, aki a tudás felé repíti az eddig statikus állapotban levő diákot. A spot egy kihívással is szembesíti a nézőt: „Képes lennél fiatalokat gondolkodásra inspirálni?” A videó szabad, nyílt tereket mutat be, sugallva a kinyíló világra való rácsodálkozást, és a tanár motivációs szerepét. Természetesen a színvilág már ismerös, a meleg sárga, világoskék színek visszaköszönnek.

A tanári pálya marketingjét segíti a jól ismert ",Those who can 't do it, teach it” (Aki nem tudja, tanitja) mottó ellentétének hangoztatása, amit a Teacher Training Agency „Those who can, Teach” (Aki tudással rendelkezik, az tanít igazán) címü videója is bizonyít. A szabad asszociációra épülö kisfilm azokat a társadalom által nagyra becsült tulajdonságokat és képességeket sorolja fel (érvelés, prezentálás, stratégiai gondolkodás, magyarázó képesség, kihívásoknak való megfelelés) ami a tanárokban is megvan ${ }^{10}$

Az előző spottal ellentétben az üzenetek közvetlenül a befogadót célozzák, az agy formájú labirintus, az egymásba váltó gondolkodást és gondolkodtatást sugalló képek a tanári képességek fontosságát jelzik. A klip végén elhangzó kérdés: „Elképzelhetőnek tartja, hogy létrehozzon egy tőkealapot?” utalhat pénzbeli, de egyben humán tőkére is. A tanár mint a világra, illetve a tudásra nyíló ablak kitárója jelenik meg a bejátszásban.

\section{A tanárhiány enyhítését célzó további eszközök}

Az ugyancsak az Oktatási Minisztérium által koordinált Premier Plus program egyik célja, hogy a legtehetségesebb diákokat nyerje meg a tanári pályára a matematika, természettudományok, számítástechnika, és vizuális müvészetek terén.

\footnotetext{
${ }^{9}$ URL: https://www.youtube.com/watch?v=IubrSO66LIE Letöltés ideje: 2016. 01.02.

${ }^{10}$ URL: https://www.youtube.com/watch?v=tGqJiTPU0F4 Letöltés ideje: 2016. 01. 02.
} 
A program a következő lehetőségeket biztosítja: személyes konzultáció kijelölt tanácsadóval, mentorálás, óralátogatás, hospitálás, konzultálás szenior tanárokkal, a jelölt bevonása az iskola társadalmi életébe, meghívás különleges iskolai eseményekre. ${ }^{11}$ Ebben a vonatkozásban emlithető meg a School Experience Program is, amelyet a National College for Training and Leadership (Országos Tanár- és Vezetőképzö Főiskola) irányít. A programban azok a hallgatók vehetnek részt, akik középiskolai tanári képesítés megszerzését tüzték ki célul. Rendszeres iskolalátogatások során a hospitálástól, a tapasztalatok megbeszélésén át eljuthatnak a tanítási gyakorlatig. ${ }^{12}$

A tanári pályával kapcsolatos stressz kezelésére, illetve a kiégés elkerülésére egyben a tanári pályán maradás elösegítésére fontos eszköznek bizonyul a coaching és a kortárs mentoring rendszer. Alred (2003) (idézi Goddard, 2004) meglátása szerint a mentorálás általános jellegü, míg a coaching egy meghatározott feladatra irányul. A mentorálás folyamán egy, a szervezet ügyeiben jártasabb munkatárs párba kerül egy pályakezdővel, vagy kevésbé tapasztalt kollégával. Fleming és Taylor (2003) úgy látja, hogy a coaching feladata a teljesítménynövelés (idézi Goddard, 2004). A coaching folyamán a munkahelyi tevékenység irányított tanulási helyzetté alakul és a résztvevők partnerként dolgoznak együtt.

Az Oktatási és Képzési Minisztérium kidolgozott egy coaching programot, amely az iskolákban alkalmazható. A kölcsönös bizalmon alapuló program elemei az órák megfigyelése, tanítási és tanulási stratégiák egyeztetése, elemzés, és reflexió. A coachinghoz szükséges tulajdonságok és képességek: értő figyelem, idő menedzsment, változás menedzsment, csapatfejlesztés, probléma megoldás, konfliktuskezelés, projekt irányítás és vezetési képességek (Goddard, 2004) jól használhatóak a tanári munka folyamán is.

Mik a mentori tevékenység előnyei? Javasolt, hogy a mentori tevékenység épüljön be a tanárképzésbe, illetve a pályakezdő tanárok integrációs folyamatába. A mentorálás segítséget nyújt a pályán maradásban, a foglalkozási kiégés elkerülésében. Segíti az iskolai, vagy intézményi kultúra jobb megértését, rugalmassá teszi a tanárnak a tanuláshoz való hozzáállását, elősegíti a szakmai fejlődést és az esetleges kudarcokból való tanulást, lehetővé teszi a személyi fejlődést, a változó munkahelyi körülményekhez való igazodást, és a tanári értékek szélesedését (Goddard, 2004).

\footnotetext{
${ }^{11}$ URL: http://www.education.gov.uk/get-into-teaching/premier-plus/benefits Letöltés ideje: 2016. 01. 02.

${ }^{12}$ URL: http://www.education.gov.uk/get-into-teaching/school-experience/sep Letöltés ideje: 2016. 01. 02. A tanárképzési programokba való belépés elősegítésének fontos eleme az úgynevezett shadowing, amely a tanár munkájának a szoros, közvetlen megfigyelését jelenti. A tanárképzési programba való belépést fontolgató hallgató árnyékként követi az általa megjelölt tanárt egy adott intervallum (általában 1-2 nap) során a munkája teljes vertikumában, Ez által fontos, közvetlen élményeket szerez.
} 
A tanári pályán maradást segíti elő a folyamatos szakmai fejlődés lehetősége is. Ebben a vonatkozásban is érdemes megemlíteni az Education and Training Foundation (Oktatási és Képzési Alapítvány) által közzétett videó prezentációt, ${ }^{13}$ amelyben már pályán levő tanárok nyújtanak információt és tanácsot a képzés elemeivel kapcsolatban. Elsősorban kiemelendő, hogy önképzésről van szó. A megszólított tanárok röviden beszámolnak arról, hogy milyen szakmai fejlesztési tevékenységet végeztek az elmúlt időszakban. A hagyományos intézményesített képzési keretek, tanfolyamok, az ismert önképző tevékenységek mellett megemlítik a saját tevékenységre irányuló reflexiót, a pedagógusi munka elvégzésének, illetve az adott erőforrásoknak az értékelését.

\section{Összefoglalás és ajánlások}

Az angol oktatási rendszer egyik fö problémája a jelentősen javuló szakmai és pénzügyi feltételek ellenére jelentkező tanárhiány, amelynek enyhítését szolgálhatja a világhálóra tolódó pályarekrutáció. A dolgozatban elemzett médiatermékek három fö szempontot emeltek ki: a tanári munka mint katartikus örömforrás, a belépési lehetőségek diverzifikálása, és a tanári pálya, illetve a tanár személye presztízsének növelése, továbbá a pályaelhagyás megakadályozása coachinggal, mentorálással. Amint látható, az elsődleges prioritás a presztízs erősítése, míg az alternatív belépési lehetőségek, illetve a folyamatos szakmai fejlődés lehetőségeinek biztosítása kisebb jelentőséggel bírnak.

Az angol modell természetesen nem vehető át egy az egyben, de több, hazánkban is alkalmazható lehetőséget tartalmaz. A Teach First program magyarországi kontextusra való adaptálása nemcsak a tanári gyakorlat megszerzését segíti elő, hanem egyben utat mutat az etnikailag és gazdaságilag hátrányos helyzetü csoportokkal szembeni sztereotip képek felszámolásához. A mozgalom ugyanis, nem csak tanárokat biztosít hátrányos helyzetủ diákokat oktató iskolák számára, hanem elösegíti a fent említett társadalmi csoportokból származó fiatalok bejutását a felsőoktatásba. Ugyanakkor a programot elvégző pedagógus nagyobb multiplikátor hatással is bír, mivel annak nagyköveteként tevékenysége nem korlátozódik az iskola szintjére. A Teach First honlapja kiemeli, hogy a program elvégzöi jelentős munkát fejtettek ki a non-profit szféra olyan területein, mint munkaerö-piaci készségek fejlesztése, szociális munka, vagy a korai iskolaelhagyás megakadályozása.

További lehetőségként említendő, hogy a Staff Room-hoz hasonló hazai virtuális iskolaportál pedig gyakorlatilag ugyanazokkal az eszközökkel megvalósítható. Ugyanakkor - amint azt a 2000-es évek első felében tett angliai oktatáspolitikai lépések mutatták - a pálya vonzerejét és a pályán maradást nagymértékben segíti az adminisztrációs terhek csökkentése is. Fontosnak találom a médiakampányt is.

\footnotetext{
${ }^{13}$ URL: https://www.ifl.ac.uk/cpd-and-qtls/what-is-cpd/ Letöltés ideje: 2016. 01. 02.
} 
A ,Senki sem felejt el egy jó tanárt” kampány mintájára a hazai elektronikus médiában is látható egy jó kezdeményezés, például a Brutális fizika címü kábel tv-s program reklámja, amely humoros formában ugyan, de az angol példához hasonló üzenetet sugall. Ugyancsak javasolt a tanárok média megjelenésének vizsgálata, illetve a tanári pálya más foglalkozásokkal kapcsolatos összehasonlítása.

Ezzel kapcsolatban jegyezném meg, hogy a tanári pályával kapcsolatos pozitív, imázsépítő hírekre, írott és nyomtatott sajtóbeli megjelenésekre nagy szükség van. A Heves Megyei Hirlap például 2015 márciusában több, a tanári professzióval kapcsolatos cikket közölt. 2015. március 4-i dátummal jelent meg egy cikk „Elégedetlen pedagógus levele" címmel. A levél kifogásolja az iskola felszerelések elégtelenségét, illetve egyes pénzbeli juttatások időbeli utalásával kapcsolatban is említ problémákat. Ugyane hónap március 14-én jelent meg egy jegyzet „Dia néni meg a lecke" (Szilvási, 2015, 3. o.) címmel. Habár az írás pozitív példát tár elénk, olyan tanárt mutat be, aki számára fontosabb a gyerekek hétvégi pihenése, mint a házi feladat erőltetése, a jegyzet főként a szakmával kapcsolatos negatív sztereotípiákat erősíti meg. A cikk írója arra mutat rá, hogy Dia néni (Tóth Diána, alsós tanár egy óbudai általános iskolában), akinek az interneten megjelent iskolatáblára írt üzenetét érdemesnek tartom szó szerint is idézni: „A hétvégére nincs lecke, hétfőn nincs dolgozat. Mindenki pihen, gyógyul, erősödik, Dia néni küldi a gyógypuszikat.” „mint humánus tanerö, ritka jelenség a magyar oktatási rendszerben.” A szerző ugyancsak megemlíti, hogy „teli vannak a hírek a pedagógusok sosem látott leterheltségével. Egy friss felmérés szerint, már most, hetekkel a tavaszi szünet előtt olyan fáradtnak érzik magukat a tanárok, mint korábban a tanév végén."

Dia néni üzenete és tanári filozófiája: „,a gyerekeket meg kell értenünk, tudnunk kell igazodni a tempójukhoz, és ami a legfontosabb, szeretettel kell nevelnünk őket. Nem a tananyag mennyisége a fontos, hanem az, hogy hogyan tanítunk meg annyit," kulcsfontosságú lehet a pedagóguspálya népszerüsítésében. Nemcsak azt sugallja, hogy a tanári hivatás, legyen az bármilyen szinten is, egyik legfontosabb eleme a gyerek vagy diák szeretete, hanem bizonyítja az OfSTED által meghatározott tanári kiválósági tényezők meglétét. Dia néni üzenete a tanár és diák közti kiváló kommunikáció, motiváló készség, a tanuló teljesítménye iránti nyitottság iskolapéldája. Nagyon fontos az is, hogy az üzenet a közösségi médián, vagyis az Y generáció által kizárólagosan preferált kommunikációs térben jelent meg. Az egyik kapcsolódó szülői hozzászólás pedig szinte önmagáért beszél: „Ez a kép, nekünk szülőknek is újra hitet adhat a pedagógus szakma elismerésében!!! Köszönjük, Dia néni!!!"14

${ }^{14}$ URL: http://www.szeretlekmagyarorszag.hu/meghoditotta-egy-tanitono-a-fb-ot-mert-nem-adott-hazit/ Utolsó letöltés: 2016. 01. 02. 


\section{Irodalom}

Goddard, B. (2004): Coaching and peer mentoring." In: Persson, M. (szerk.): Towards the teacher as a learner: Contexts for the new role of the teacher. Learning Teacher Network, Karlstad. 47-54.

Hargreaves, L. (2009): The status and prestige of teachers and teaching. In: International Handbook of Research on Teachers and Teaching. 2017-2229. URL: http://link. springer.com/ chapter/10.1007\%2F978-0-387-73317-3_13\#page-1 Letöltés ideje: 2015. 02. 08.

Harris, A., Bennett, N. és Preedy, M. (2003): Organizational effectiveness and improvement in education. Open University Press, Berkshire.

Lendvai Edina és Gál József (é. n.): Marketingkommunikáció I. URL: www.tankonyvtar. hu/hu/tartalom/.../marketingkommunikacio_1.docx Letöltés ideje: 2015. 05. 19.

Paton, G. (2014): Schools warned over looming teacher recruitment 'crisis'. URL: http:// www.telegraph.co.uk/education/educationnews/11258232/Schools-warned-overlooming-teacher-recruitment-crisis.html Letöltés ideje: 2015, 05. 19.

Recruitment of ethnic minorities (2008-2011) URL: https://www.tes.co.uk/article.aspx? storycode $=2622901$ Letöltés ideje: $2015,02.07$.

Staff Room (é.n.): URL: https://getintoteaching.education.gov.uk/?utm_source=education. gov.uk/get-into-teaching/\&utm_medium=referral\&utm_campaign=link-to-beta-site-fromtoolbar Letöltés ideje: 2015. 02. 08.

SzilágyiZoltán és Veres Zoltán (2007): A marketing alapjai. Perfekt Kiadó, Budapest.

Szilvási Zsuzsa (2015): „Dia néni meg a lecke.” Heves Megyei Hírlap, XXVI évf. (62) 2. sz.

\section{Internetes források}

URL: https://www.ifl.ac.uk/cpd-and-qtls/what-is-cpd/ Letöltés ideje: 2016. 01. 02.

URL: http://www.education.gov.uk/get-into-teaching/school-experience/sep Letöltés ideje: 2016. 01. 02.

URL: https://www.youtube.com/watch?v=tGqJiTPU0F4 Letöltés ideje: 2016. 01. 02.

URL: https://www.youtube.com/watch?v=IubrSO66LIE Letöltés ideje: 2016. 01. 02.

URL: https://getintoteaching.education.gov.uk/why-teach/career-changers Letöltés ideje: 2016. 01.02.

URL: https://www.tes.co.uk/article.aspx?storycode=2622901 Letöltés ideje: 2016. 01. 02.

URL: http://www.teachfirst.org.uk/home Letöltés ideje: 2016. 01. 02.

URL: https://getintoteaching.education.gov.uk/ Letöltés ideje: 2016. 01. 02.

URL: https:/www.gov.uk/government/news/your-future-their-future-new-teacher-recruitmentcampaignhttps://www.gov.uk/government/news/your-future-their-future-new-teacherrecruitment-campaign Letöltés ideje: 2016. 01.02.

URL: http://www.telegraph.co.uk/education/educationnews/11258232/Schools-warned-over -looming-teacher-recruitment-crisis.html Letöltés ideje: 2016. 01. 02.

URL: http://www.telegraph.co.uk/education/educationnews/11258232/Schools-warned-overlooming-teacher-recruitment-crisis.html Letöltés ideje: 2016. 01. 02. 